In cooperation with the West Virginia Department of Health and Human Resources, Bureau for Public Health,

Office of Environmental Health Services, Environmental Engineering Division, and the

West Virginia Department of Environmental Protection, Division of Water and Waste Management

\title{
Methane in West Virginia Ground Water
}

\section{Introduction}

Methane has been found as a dissolved gas in numerous ground-water samples from water wells in West Virginia. Methane $\left(\mathrm{CH}_{4}\right)$ is a colorless, odorless, tasteless gas that can cause oxygen-deficient atmospheres, flammable situations, or explosive environments. Methane can ignite at atmospheric concentrations between 5 and 15 percent, and higher concentrations of methane can quickly dilute to flammable levels. Thus, the accumulation of methane gas in an enclosed area may cause an explosive environment in which an ignition source such as an electrical outlet, pilot light, match, or even a well pump could trigger a violent explosion. In addition to the obvious hazards associated with explosions, the breathing of methane in high concentrations can lead to asphyxiation, and the burning of methane produces toxic gases (Eltschlager and others, 2001).

Potential sources of methane gas, also referred to as natural gas, firedamp, and marsh gas, include active and abandoned coal mines, improperly constructed gas wells, decaying organic matter, landfills, and swamps. Methane is often generated and stored in sedimentary rocks associated with coal beds and with oil and gas fields. Coal-bed methane is a result of the microbial or thermal alteration of organic matter during coal formation. The methane originates in the coal units or often in carbonaceous shales, but it may migrate to other geologic units conducive to storage, such as overlying, permeable sandstones (Eltschlager and others, 2001).

Methane gas can be transported by ground water in dissolved or pure gaseous states. Methane in ground water is not explosive; but when water containing dissolved methane comes into contact with air, the methane quickly escapes from the ground water into the atmosphere. If this process occurs in a confined space, then the methane could ignite; or if it is allowed to accumulate, it could explode. Because the solubility of methane in water is between 28 and 30 $\mathrm{mg} / \mathrm{L}$ (milligrams per liter), well water samples with concentrations of dissolved methane greater than $28 \mathrm{mg} / \mathrm{L}$ could liberate potentially explosive or flammable quantities of gas inside the well or in confined spaces in well houses or structures containing wells. Concentrations of methane greater than $10 \mathrm{mg} / \mathrm{L}$ but less than $28 \mathrm{mg} / \mathrm{L}$ are a possible indication that methane concentrations may be increasing to dangerous levels in ground water (Eltschlager and others, 2001).

\section{Occurrence and Distribution of Methane in West Virginia Ground Water}

From 1997 to 2005, the USGS sampled ground water using standard sampling protocols (Koterba and others, 1995) from 170 wells in West Virginia for dissolved gases, including methane. Replicate dissolved-gas samples were collected for each well; the averaged dissolved-gas concentrations for each well are reported in White and Mathes (2006), and averaged methane concentrations are described herein. Methane concentrations in ground water for the 170 wells ranged from not detected to $68.5 \mathrm{mg} / \mathrm{L}$. Methane was detected in 131 of 170 of these wells and was present in concentrations greater than $28 \mathrm{mg} / \mathrm{L}$ in 13 of these wells. Another 13 wells had methane concentra-

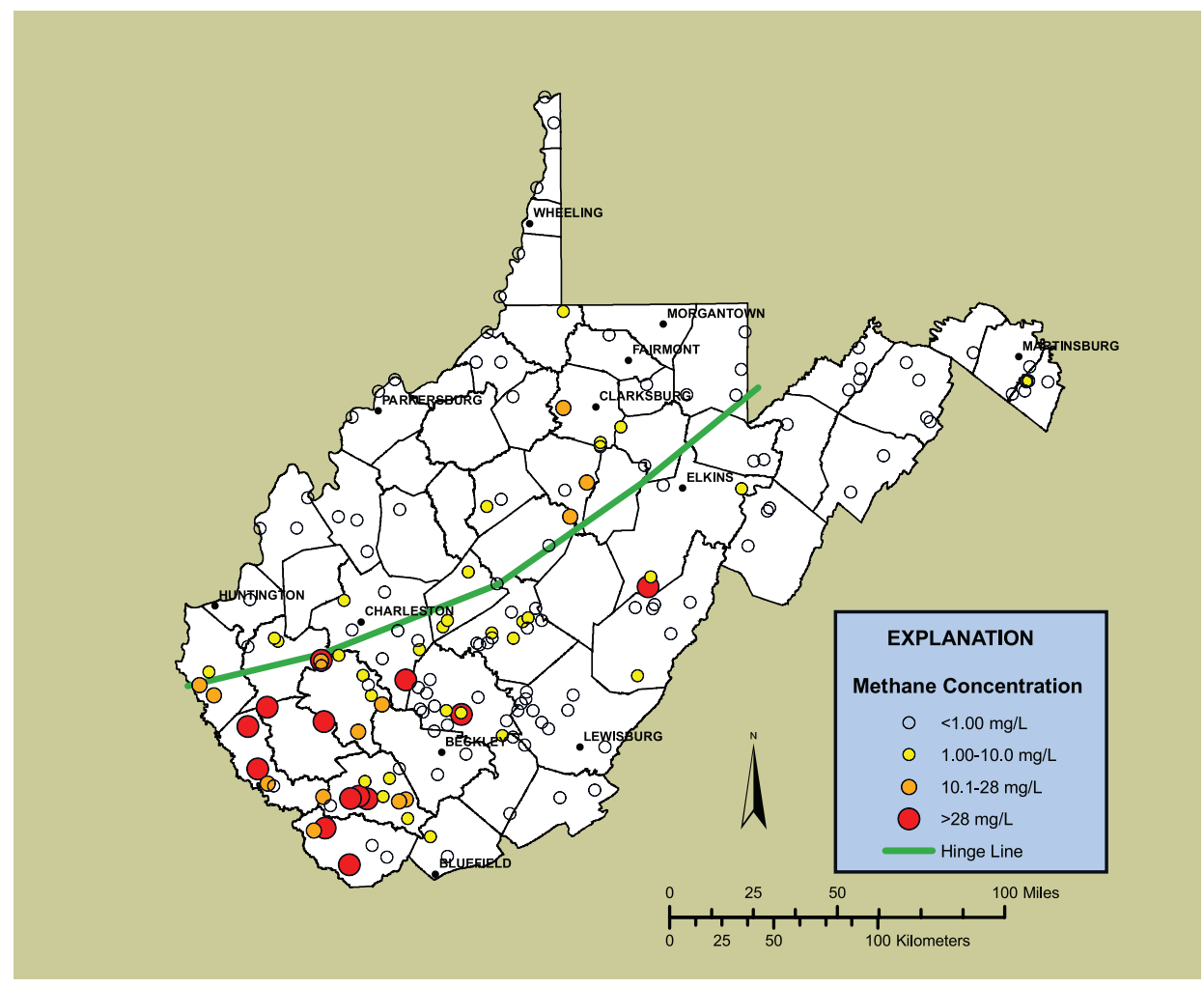


tions ranging from 11.9 to $24.3 \mathrm{mg} / \mathrm{L}, 32$ wells had concentrations ranging from 1.00 to $10.0 \mathrm{mg} / \mathrm{L}$, and 73 wells had detectable methane concentrations less than $1.00 \mathrm{mg} / \mathrm{L}$. Methane was detected in wells in 43 of the 47 counties sampled, but methane concentrations exceeding $10 \mathrm{mg} / \mathrm{L}$ were found in wells in only 11 counties, with 22 of 26 of these samples from eight counties located in the southern coal fields of West Virginia. All but three of these samples were south of the "hinge line" (Arkle, 1969) that separates the lower-sulfur coal deposits of southern West Virginia from the higher-sulfur coal deposits of northern West Virginia. Most (23 of 26) of the samples with methane concentrations greater than $10 \mathrm{mg} / \mathrm{L}$ were from wells with water-bearing zones in rocks of Pennsylvanian age, with one sample from Permian age rocks, one sample from Mississippian age rocks, and one sample from Devonian age rocks.

No samples with methane concentrations greater than $10 \mathrm{mg} / \mathrm{L}$ were found in Quaternary alluvium or in rocks older than Devonian age (table 1). Methane concentrations exceeding $10 \mathrm{mg} / \mathrm{L}$ were found in wells located in valleys and on hillsides but not in wells located on hilltops.

\section{Action Levels}

The U.S. Department of the Interior, Office of Surface Mining (Eltschlager and others, 2001), advises owners of wells with dissolved methane concentrations greater than $28 \mathrm{mg} / \mathrm{L}$ to immediately contact their local county health department to obtain assistance and guidance in venting the wellhead and for other possible remediation alternatives. Methane will not accumulate in the wellbore if the well is properly vented to the air. Owners of wells with methane concentrations greater than $10 \mathrm{mg} / \mathrm{L}$ but less than $28 \mathrm{mg} / \mathrm{L}$ might also wish to contact their local county health department for further assistance and might consider removing ignition sources from the immediate area. Methane concentrations less than $10 \mathrm{mg} / \mathrm{L}$ require no action, other than periodic monitoring to see if methane concentrations are changing. The West Virginia Bureau for Public Health advises that private well owners requiring additional information about methane contact their local county health department. Public water supply systems in West Virginia are advised by the West Virginia Bureau for Public Health to contact one of

Table 1. Distribution of methane with respect to geologic age.

\begin{tabular}{lrrrrr}
\hline \multirow{2}{*}{$\begin{array}{c}\text { Geologic age of water- } \\
\text { bearing rocks }\end{array}$} & \multicolumn{5}{c}{$\begin{array}{c}\text { Number of samples with the indicated methane } \\
\text { concentrations (in milligrams per liter) }\end{array}$} \\
\cline { 2 - 6 } & $\mathbf{2 8}$ & $\mathbf{1 0 . 1 - 2 8}$ & $\mathbf{1 . 0 0 - 1 0 . 0}$ & $<\mathbf{1 . 0 0}$ & $\begin{array}{c}\text { Not } \\
\text { detected }\end{array}$ \\
\hline Quaternary alluvium & 0 & 0 & 0 & 9 & 2 \\
Permian & 0 & 1 & 1 & 4 & 3 \\
Pennsylvanian & 11 & 12 & 26 & 35 & 13 \\
Mississippian & 1 & 0 & 1 & 15 & 6 \\
Devonian & 1 & 0 & 3 & 9 & 8 \\
Silurian & & & No wells sampled & \\
Ordovician & 0 & 0 & 0 & 0 & 7 \\
Cambrian & 0 & 0 & 1 & 1 & 0 \\
\multicolumn{1}{c}{ Total samples } & 13 & 13 & 32 & 73 & 39 \\
\hline
\end{tabular}

${ }^{1}$ All detections of methane with concentrations less than 1.00 milligram per liter.

the following West Virginia Department of Health and Human Resources, BPH-EED District Offices:
Beckley
(304) 256-6666
Kearneysville
(304) 725-9453
Philippi
(304) 457-2296
St. Albans
(304) 722-0611
Wheeling
(304) 238-1145

or the central Charleston BPH-EED

office at (304) 558-2981.

\section{References Cited}

Arkle, Thomas, Jr., 1969, The configuration of the Pennsylvanian and Dunkard (Permian?) strata in West Virginia; a challenge to classical concepts, in Donaldson, A.C., ed., Some Appalachian coals and carbonates-Models of shallow water deposition, Preconvention Geological Society of America Field Trip, November 1969: West Virginia Geological and Economic Survey, p. 55-88.

Eltschlager, K.K., Hawkins, J.W., Ehler, W.C., and Baldassare, Fred, 2001, Technical measures for the investigation and mitigation of fugitive methane hazards in areas of coal mining: Office of Surface Mining Reclamation and Enforcement, 125 p.

Koterba, M.T., Wilde, F.D., and Lapham, W.W., 1995, Ground-water data-collection protocols and procedures for the National Water-Quality Assessment Program-Collection and documentation of water-quality samples and related data: U.S. Geological Survey Open-File Report 95-399, 133 p.

White, J.S., and Mathes, M.V., 2006, Dissolved-gas concentrations in ground water in West Virginia: U.S. Geological Survey Data Series 156, 8 p., available online at http://pubs.water.usgs. gov/ds156/

—M.V. Mathes and J.S. White

\section{For Additional Information}

For information on USGS products and services, call 1-888-ASK-USGS or visit the ask.usgs.gov Web site or the USGS home page at http://www.usgs.gov/. 